\title{
Alice Walker and Her Womanist Aesthetics
}

\author{
D. Bhagyathara* \\ Associate Professor \& Head, PG \& Research Department of English, Vellalar College for Women (Autonomous), \\ Erode, Tamilnadu, India; bagi1957@rediffmail.com
}

\begin{abstract}
Womanism emphasizes the ideals of black life by giving a balanced presentation of black womandom. Its objective is the dynamism of wholeness and self-healing. Alice Walker has evolved a working-base to envision her womanist aesthetics. It is outlined in In Search of our Mother's Gardens: Womanist Prose (1983) which provides for the womanists of today a model of womanist praxis.
\end{abstract}

Keywords: Class, Gender, Oppression, Race, Survival, Wholeness, Womanist Aesthetics

\section{Introduction}

Alice Walker is regarded as a writer of powerfully expressive fiction. Her works consistently reflect her concern with racial and political issues, particularly with the black woman's struggle and political survival. Walker's works just do not deal with women and women's issue but posit some aspects of womanist ideology.

\section{Womanism: Definition and Concepts}

Alice Walker has introduced the term 'Womanist'/'Womanism' into feminist parlance as an instrument of lexical and cultural difference between black and white feminists who cannot seem to unify on issues of race, class and gender. Perhaps, a womanist is from an ethical and spiritual perspective - by definition and by common usage a woman of color, a woman who has inevitably viewed life and society from the underside [4]. Thus the two terms, "black feminism" and "womanism" can be seen as interchangeable because both are concerned with the struggle against racism and sexism by black women who are themselves part of the black community's effort to achieve equality and liberty.

In a letter published in New York Times Magazine Walker says:

Feminism (all colors) definitely teaches women they are capable, one reason for its universal appeal. In addition to this womanist (ie., black feminist) tradition assumes, because of our experiences during slavery that black women already "are" capable..... [5]

One of Walker's earliest written articulations of her womanist aesthetic appeared in her 1983 review of Jean McMahon Humez's Gifts of Power: The Writing of Rebecca Cox Jackson, Black Visionary, Shaker Eldress (1981). She writes that she could "imagine African-American women who love women (sexually or not) .... Referring to them as 'whole' women .... As 'round' women .... who also have concern, in a culture that oppresses all black people.... My own term for such women would be "womanist" [4].

Walker further explains in that the term would need to express the "spiritual and the concrete and it would have to be organic, characteristic, not simply applied" and "connectedness to the entire community and the world" [4]. She defended her choice of term to

*Author for correspondence 
Audre Lorde, pointing out that her use of "womanist", rather than "Black feminist", was "a necessary act of liberation to name oneself with words that fit". In addition, "womanist" offered more room for changes, especially Southern culture" [3].

\section{Walker's Womenist Aesthetics: A Working Base}

Walker sets out her womanist aesthetics as the preface for In Search of our Mother's Gardens: Womanist Prose, that the word "womanist" is:

From womanish (Opp. "girlish', i.e., frivolous, irresponsible, not serious) a black feminist or feminist of color... Interested in grown-up doings. Acting grown up. Interchangeable with another folk expression, "You trying to be grown. Responsible. In charge" [4].

Walker's definition of the attitude exhibited by the womanist's subject is broad enough, and flexible enough, to invoke Maria Steward's boldness in making political speeches to men and women long before society deemed it proper for woman (let alone a black woman ) to do so. Thus while one must continue to credit Walker for having set down the terms for a womanist aesthetic, her acknowledged debt to certain fore-mothers, who served as trail- blazers, is as apparent as in her own influence on a growing body of women's literature and criticism worldwide.

The most obvious is Zora Neale Hurston whose exuberant spirit is easily recognizable in Walker's definition of the womanist attitude. Along with Hurston, Walker directly invokes Harriet Tubman an escaped slave and an underground railroad conductor, in setting out her definition. She also draws from a documentary legacy of African-American woman who exhibited the kind of courageous, wilful, audacious, womanist behaviour that Walker includes as part of her definition. Walker's description of the womanish approach to life as the spirit of woman such as Rebecca Cox Jackson, Jarena lee, Zilpha Elaw and Sojourner Truth who went against the grain and challenges prevailing notions about what women (who were also of African descent) could not do. One is reminded also of Harriet Jacobs agency in her direct challenge to legal and social structures that made it permissible for a white man to demand her total submission to his will.
More than a decade before Walker spelled out her womanist aesthetic, the character of Ruth Copeland exhibited aspects of womanist attitude in The Third Life of Grange Copeland (1970). Precocious and womanish as a young girl, Ruth clearly exhibits the attributes of the potential womanist subject. The title character of Meridian (1976) epitomizes the courageous, wilful behaviour of the womanist subject. In The Color Purple (1982), Walker achieves a previously unrealized depiction of the womanist approach to life in the character of Shug Avery. Like Meridian Hill, Shug Avery is comfortable in choosing an alternative to mothering. She leaves her children to pursue a career as a blues singer, an act considered scandalous by many. Sofia also displays the womanist attitude in refusing to allow Albert (her future father-in-law) to define her out-of-wedlock pregnancy in negative terms. Lissie, of The Temple of My Familiar (1989), is Walker's neologism made flesh. She is living history, exemplifying the womanist spirit of knowledge.

Walker affirms that a womanist is bold, brassy and universalist:

Also a woman who loves other women, sexually and or non sexually. Appreciates and prefers women's culture, women's emotional flexibility and women's strength. Sometimes loves individual men, sexually and/ or non sexually. Committed to survival and wholeness of entire people, male and female [4].

The second component of Walker's womanist aesthetics describes the womanist vis-à-vis her relationship with others and with herself, stresses connectedness over separatism, encourages an acceptance of a collective past as it is exhibited in many hues of the African diaspora, and celebrates a legacy of resistance to oppression. Walker's womanist is in touch with her own fluid sexuality, which she shares at her discretion and pleasure with women and / or men. The womanist embraces and openly expresses her sexuality in relationship with others.

In The Color Purple, Walker gives the Celie / Shug / Albert triad. Though Walker posits sexuality as a good thing, relationships can be sexual or not sexual. Lissie provides a veritable history of human sexuality in The Temple of My Familiar. Nevertheless, she and her husband Rafe continue to enjoy a close intimate relationship even after he no longer desires her sexuality. They form a triad with Lissie's lover Hal. Tashi's 
story represents the importance of unencumbered sexuality via negative in Possessing the Secret of Joy. Though she is unable to experience sexual joy after her voluntary circumcision, Tashi does not condone her husband's affair with Lissitte. It is Lissitte who willingly accepts her role in the triad, who expresses her sexuality freely, and thus better exemplifies this aspect of the womanist. Walker begins her acknowledgements at the end of By the Light of My Father's Smile by thanking the spirit of Eros, for the novel celebrates the erotic.

Walker highlights another dimension of the womanist as exultant in spirit and erotic who, "Loves Music. Loves dance. Loves the moon. Loves the spirit. Loves love and food and roundness. Loves struggle. Loves herself. Regardless" [4].

Walker's third component emphasizes sensual pleasure. This aspect of Walker's womanist process is most evident in Shug Avery, the blues singer and fitting guide in Ciele's experiences of sensual pleasure. Walker best develops the third component of her definition in $B y$ the Light of My Father's Smile. Manuelito and his Mundo clan are a natural people, the folk, who celebrate the sensual pleasures, living in accordance with nature's cycle.

The fourth tenet, Walker says that a womanist is purple with rage, purple as restored royalty, purple blossoming wild in an open field. She states: "Womanist is to feminist as purple to lavender" [4].

The fourth component of Walker's womanist process is comprised of a single straight forward statement that has, nevertheless, invited much critical analysis. Dorothy Grimes writes that the analogy is apparently intended to capture the texture and intensity of womanist as opposed to feminist.

Tuzyline Jita Allan offers that "even with the filter of metaphor, the last statement fails to conceal the deep lines of division drawn here between black and white feminist" [1]. To enhance one's understanding of the last component of Walker's womanist aesthetic, it is important to consider the other three components, as well as how Walker enacts her womanist project in her fiction.

The first tenet set out the proper womanist attitude or approach to self-actualization though it specified that a womanist is a black feminist or a feminist of color, the qualities Walker delineates for the womanist are qualities that anyone might exhibit. Walker has demonstrated this time and again in her fiction. The second component, fuses on relationships, and here Walker tries to avoid the self-and-other split that drives Western dualism. The third component invites the unbridled expression of love of all living things, an appreciation for the natural world and its cycles, and the experience of sensual pleasure. The last idea would be in keeping with Walker's focus on connectedness. Purple, a more intense color than lavender, is not merely the result of adding black to lavender, it also symbolizes the place of black women in American society, who like Celie must find a way to resist multiple oppressions related to race, class, gender and sexuality and to survive whole. Walker's womanist aesthetics is flexible enough to include her hopeful vision of wholeness for an ever-expanding community is clearly obvious.

The layered meaning of Walker's womanist aesthetics is in keeping with her refusal to adopt any ideological pattern that is narrow and restricted and therefore out of harmony with her spirituality. It reflects her commitment to balance the beauty and power which make her womanist aesthetic distinctive and healing. There is a balance in her thought and in all of her art- balance between concern for women's reality and concern for the larger universe to which black women, like all people, are connected.

\section{Conclusion}

The universalist philosophy that Walker invokes as part of her womanist theory is expressed by her image of the garden, where room is present for all flowers to blossom unvaryingly and yet in their own way, living together nonetheless preserving their cultural uniqueness and integrity. In these aspects of the concept of womanism, one can see the balancing nature of one's personallifeinrelationtoone'spoliticallife. ThoughWalker's process is allegedly de-centred, the quest for individual and collective harmony is the one aspect of the process that is most apparent in all of her novels. Besides, she envisions, "survival whole" for the entire black community. This lends credence to Ogunyemi's assertion that Alice Walker has finally emerged as a spokeswoman for black women and the black race by moving away from black male chauvinism and the iconoclastic 
tendencies of feminism to embrace the relative conservatism of womanism. Womanism with its wholesomeness, its religious grounding in black togetherness is her gospel of hope [2].

\section{References}

1. Lauret, M. Alice Walker's Life and Work: The Essays. Qtd from Tuzyline Jita Allan New York: Palgrave MacMillan, 2011.
2. Ogunyemi, C.O. Womanism, The Dynamics of the Contemporary Black Female Novel in English. Signs II. 1985. 163-180.

3. Walker, A. Anything We Love can be Saved: A Writer's Activism. New York: Ballantine Books, 2011.

4. ---.In Search of our Mother's Gardens: Womanist Prose. London: Women's Press, 1983.

5. ---.The Black Woman's Story. The New York Times Magazine. 1984 Feb 12. Available: www.nytimes.com 